\title{
Exploring the sacrality of reading as a social practice
}

\author{
María Angélica Thumala Olave ${ }^{1}$
}

Accepted: 19 March 2021 / Published online: 3 April 2021

(c) The Author(s), under exclusive licence to Springer Nature Limited 2021

\section{Introduction}

During the first half of 2019, the National Museum of Scotland in Edinburgh put on an exhibition called Robots. It displayed a range of artefacts, from early mechanised human forms to more elaborate recent technology. The exhibition contained more than 100 objects - automatons, science fiction film stars and contemporary robots created in research laboratories. The curators' objective was to reveal "our 500-year quest to make machines human" (National Museum of Scotland 2019). The main promotional poster of the exhibition displayed a REEM service robot, built by PAL Robotics in Spain in 2016. The friendly (or at least harmless)-looking white and black humanoid robot in the poster stands holding a book and appears to be reading it.

The notion that "reading is what makes us human" is prevalent among people immersed in bookish cultures. The phrase often refers to reading for pleasure or curiosity as distinct from literacy, the capacity to decode texts, which is required for formal instruction and work. Literary scholar Alberto Manguel writes: "I believe that we are, at the core, reading animals and that the art of reading, in its broadest sense, defines our species. We come into the world intent on finding narrative in everything: in the landscape, in the skies, in the faces of others, and of course, in the images and words that our species creates" (Manguel 2010, p. ix). Reading as an expression of shared humanity and a vehicle for the formation of the self in relation to others is a recurring trope in the accounts of their reading practices among lay readers in the United States (Long 2003; Aubry 2011; Sweeny 2010), the United Kingdom (Taylor 2019; Thumala Olave 2018; Hartley 2001; Billington 2011; Reed 2002) or China (Wu 2014). The facts that not all human societies, or groups within them, have employed or employ written texts as the main means for the creation, communication and storage of information or art, or that narrative is not intrinsic to written texts remain in the background, if they are considered at all, by these readers. This is in large part because of the enormous symbolic and material power of the written word and of one of its most famous carriers, the book. The use of print in

María Angélica Thumala Olave

angelica.thumala@ed.ac.uk

1 University of Edinburgh, R1.02, 21 George Square, Edinburgh EH8 9LD, UK 
processes of modernisation, nation-formation, imperial expansion, Evangelisation, and colonialism (Dunch 2002; Kirsch 2007; Anderson 1983; Habermas 1989), the spread of the written word, has resulted, on one hand, in the routinisation of texts, their social remediation (Bolter and Grusin 2000) beyond literate elites and reading cultures. Texts and the reading of them can "disappear" because they work (and until they don't), embedded as they are in social organisation: bureaucracy, education, science, commerce, digital platforms' user interfaces and a large part of what circulates digitally. Ensuring the literacy of their populations is one of the missions of governments all over the world (Meyer et al. 1992). Countries' educational institutions operate with "the fundamental assumption that reading is intimately tied to the development, transformation, or maintenance of the social order" (Griswold et al. 2011, p. 25). At the same time, the ritual and revelatory role of particular textual objects in religion (Judaism, Christianity and Islam are "religions of the book") and in scientific and philosophical thought and the associated metaphor of "the book of nature" (Blumenberg [1981] 2000) converge with the functional uses of reading to make books and reading sacred, objects and practices worthy of protection (Alexander 2003, p. 186) and promoted by state and civil organisations like no other cultural practice (Griswold et al. 2005).

My wager for this editorial introduction to the special issue on the cultural sociology of reading is that contemporary leisure reading, the focus of the issue, is done in the context and under the shadow (or the light!) of the prestige and sacralisation of books and texts. A cultural sociology of reading as a social practice examines the valuations, attractions and influence of texts and books in a way that incorporates their sacred status, social history and transformative power without reducing their import and the experience of them to the conditions of texts' production and consumption or seeing them as signs of the text or of the reader's social position (Thumala Olave 2018).

Griswold et al. (2011, p. 23) note that "all societies with written language have a reading class, but few have a reading culture". In a reading culture reading is "expected, valued, and common" (Griswold et al. 2011, p. 23). A reading class is defined by "its human capital (education), its economic capital (wealth, income, occupational positions), its social capital (networks of personal connections), its demographic characteristics (gender, age, religion, ethnic composition), and-the defining and noneconomic characteristic-its cultural practices" (Griswold et al. 2011, p. 23) The "reading class" (Griswold et al. 2005) tend to be urban, educated, relatively affluent, white, women and in countries with nearly full literacy it is estimated that about $15 \%$ of adults are "heavy readers" (Griswold et al. 2011, p. 23). It is the reading class who buy and borrow books, attend book festivals and sustain the book cultures of the countries whose reading practices are discussed in this special issue, the Anglophone area formed by the United States, the United Kingdom and Australia, the Czech language cultural space, and the transnational space constituted by the readership of the Colombian author Gabriel García Marquez. It is the members of these small reading classes who benefit most from the reading infrastructure, the state and market institutions that support access to books and reading (Griswold 2000). However, a cultural sociology of reading does not centre the analysis on the social structuration of taste or the variations in reading practices and preferences 
associated with various forms of capital across social categories. These connections have been explored at length by the existing sociology of reading, in ways that, to various degrees, neglect the existential and aesthetic meanings of books, texts and reading (Thumala Olave 2018).

A cultural sociological interpretation of reading involves conceptualising texts' and books' power as emerging from the realisation or actualisation of highly valued social goods (Charles Taylor's "hypergoods" Taylor 1989, Leypoldt's objects of "strong evaluation", in this issue, and those belonging in Alexander's "civil sacred" Alexander 2006). The cultural sociology of reading, in the version that I propose (Thumala Olave 2018, 2020), explores how these goods emerge in the practical fusion of the properties of texts and books as cultural objects and the reading experience. The aim is to dissolve the dichotomy between communication and the sensorial, which pervades the efforts to understand our interaction with cultural objects in both literary studies and the sociology of culture. What is the exact nature of the relationship between texts, subjectivities and social context? Is the encounter between text and reader determined or open? Does attention to history, political economy or institutions risk neglecting the textual object itself or its subjective impact? Can we disentangle the various factors influencing reading and the valuation of texts? What part does each element (the reader, the book/textual object, the act of reading, the context) play in "bringing about" (Hennion and Muecke 2016, p. 296) these goods? How do we capture the contingent, creative and unforeseeable results of the interaction between these elements? (Gomart and Hennion 1999). The cultural sociology of reading takes seriously both the textual object and the reader's experience; it does not seek to unmask the object as a sign of something else nor does it reduce the reading experience or the attachment to books and texts to a status game.

In what follows I explain further the project of a cultural sociology of reading and how reading is investigated within this broad perspective. I combine my own ideas for and work on this project with that of six scholars who, from a variety of standpoints and using a range of methodologies, have investigated the valuation of literature and literary value (Leypoldt, Santana Acuña, Allington), the iconic properties of textual objects (Watson and Bennett, Ván̆a) and how romance reading constitutes an aesthetic civil sphere (Michelson). My final remarks broaden the scope by shifting the attention from reading among lay readers to the theme of reading and social theory. I propose that a cultural sociology of reading can contribute to the exploration of the links between styles of reading and styles of theorisation.

\section{What is a cultural sociology of reading and how is it done?}

The cultural sociology of reading is an approach to the study of reading as a social practice and to books and texts as cultural objects. It is an affirmative stance that centres on the meanings - aesthetic, existential, political, ethical-which emerge in the interaction between readers and textual objects. It asks why reading matters to people, why readers care for their reading practices in general and for particular texts, what their attachment looks like and what sustains it, how the materiality and 
iconicity of books and other textual objects shapes readers' attachment to them, how readers, lay and professional, evaluate these objects and how the criteria deployed in processes of evaluation are tied to cultural scripts and personal value commitments (Thumala Olave 2018, 2020).

The approach takes seriously the subjective accounts offered by readers of their reading experiences and seeks to do justice to the perceived uniqueness of the encounter with books and texts, the personal impact of this interaction, and the extent to which its meanings can only be partly communicated to others. The cultural sociology of reading is attuned to the subjective depth in readers' attachments to their reading histories and to what they read. At the same time, it situates these accounts in relation to shared cultural codes and hierarchies of value that have a history. The cultural sociology of reading is located in between, on one hand, the kind of phenomenological analyses offered by scholars in the humanities (e.g. Steiner 1978; Sontag 1967; Benjamin [1955] 2015; Manguel 2010, 1997), whose poetic renderings of the meanings of reading and books brim with beauty and erudition but do not seek to offer scientific evidence, and on the other, the sociology of reading interested in meaning but concerned with different questions, the important work of scholars like Wendy Griswold (Griswold 2000, 1981; Griswold et al. 2005), Elizabeth Long (2003) and Clayton Childress (Childress 2017; Childress and Friedkin 2012). This scholarship examines the institutions and apparatuses that support reading (Griswold) and the collective production of meaning in reading groups (Long, Childress). The cultural sociology of reading builds on this work and pays closer attention to individual readers' subjectivity and aesthetic, affective responses as well as the long-term role of reading on the individual's life and sense of self in the context of shifting and enduring social valuations of reading, books and other textual objects. There is no question that all reading is inherently social (unlike talk, which is "pre-wired" in the brain, reading must be taught (Wolf 2018), and even in solitude it involves social interaction, with authors, narrators, real or imagined readers, and the self). Yet most reading continues to happen outside reading groups and only a part of it is communicated to others. The cultural sociology of reading goes deep into the aesthetic and existential meanings of reading and how these are bound to the material properties of books and other textual objects, a dimension of reading that the current sociology of reading does not address.

The existing research can be grouped into three areas of concern: first, literacy and resistance, as pursued by cultural studies scholars (e.g. Barton and Hamilton 1998; Radway 1991; Street 1993; Sweeny 2012); second, cultural capital and the structuration of taste, as developed by field theory researchers and scholars following sociologist Pierre Bourdieu (e.g. Nagel and Verboord 2012; Bennett et al. 2009; Driscoll 2014; Atkinson 2016); and third, the history and institutional apparatuses that shape and enable reading (Griswold 2000; Long 2003; Childress 2017).

The cultural sociology of reading is different from both cultural studies and the work that follows Bourdieu. Against the critique of the cultural industry and its concern with passivity, cultural studies work has rightfully shown that readers contest and creatively appropriate books' contents for their own needs in a wide range of contexts (Barton and Hamilton 1998; Sweeny 2012, 2010). But while it is true that most readers are not cultural dupes, the full range of the relationships that people 
have with texts is not captured by the binary indoctrination/resistance. Reading can be critical of course and the attachment to books on this basis has been eloquently narrated by a plethora of readers, from autodidact workers in Britain (Rose 2001) to literary figures (Winterson 2012; Baldwin and Mead 1971). What these accounts of reading as awakening, salvation or a "way out" show is that reading is also an affirmative experience, a source of solace and joy. As academics know well, pleasure is not antithetical to critical reading or reading for knowledge and understanding (Aubry 2018). Tying the transformative power of reading to resistance alone leaves out what is generative and underdetermined in the aesthetic encounter between books/texts and readers. The same applies to the material dimension of reading. Thanks to a combination of technology and the law, e-books have been produced with a limited ability for users to control them and make them their own (Borsuk 2018; Price 2019; Striphas 2009). While some readers may be pushing back, as Striphas (2009) shows, the motives for continuing to read print as opposed to digital books that I have found in my research with readers in the UK are less often about a "refusal" to "defer to the industry" (Striphas 2009, p. 185) than about the sensorial and aesthetic appeal, the strength of attachment to the codex and the affective responses its sensual properties afford. Less a case of pushing back against economic forces than of being pulled in by the pleasures of "active passion" (Gomart and Hennion 1999).

On the other hand, from the research on the structuration of taste and the legitimacy of cultural products developed in Bourdieusian analyses, we learn that the better educated and women read more and that readerly tastes are socially structured (e.g. Atkinson 2016; Bennett et al. 2009). This work, however, does not explore what readers do with books once they have selected them, what texts do to readers, why readers care about their reading and books, or why they are moved, repelled, bored or changed by them. This scholarship has also little to say about the outcomes of reading for the self and its relationship with the world, beyond the affirmation of status or the accumulation of various forms of capital.

A cultural sociology of reading pays attention to the contingent and generative interaction between book/text, reader and context without prioritising one over the other; it seeks to capture the aesthetic and existential import of reading and the non-textual interaction with books and other textual objects. Unlike book historians who have for long examined books as material objects (e.g. Chartier 2018), the sociology of reading has yet to incorporate books' physical properties both conceptually and empirically. My own ongoing research on this seeks to contribute theoretically by drawing on theories of the icon (e.g. Peirce 1931; Boehm 1994; Alexander et al. 2012; Alexander 2008, 2010, 2020), attachment (e.g. Gomart and Hennion 1999; Hennion and Muecke 2016; Hennion 2004, 2007) and reception (e.g. Iser 1980; Jauss 1982; Altieri 2003; Phelan 2007; Felski 2008, 2020) in order to advance a novel interpretation of the love for books. I use a two-part model that covers the interplay of (i) books' material surface and symbolic depth, and (ii) readers' activity and passivity. Empirically, I have begun to show how the attachment to books in the United Kingdom emerges in the practical fusion of three elements that have so far been considered separately: the material, surface properties of books; the act of reading; and the sacred goods that books represent and realise. I have demonstrated that the love for print 
books in particular-expressed in the desire to be in their presence and the difficulty of parting with them-can be productively explored by conceptualising books as icons. The book is iconic in three ways. First, the codex (a bound, print copy) is one of the most easily and immediately recognisable cultural objects. While books' form and content has changed over time, the idea of the codex strongly shapes the meanings of reading today. Second, any individual print copy of a book is simultaneously a type of highly valued, sacred cultural goods and an instantiation of the type, a token of the realisation of these goods for each individual reader. Among these goods are cultivation, social mobility, civility, pleasure, physical well-being, social cohesion, or the preservation of intellectual and artistic heritage. Books embody "an image of the good with which social actors seek community and strive to protect" (Alexander 2003, p. 186). Third, books become icons through immersion into them as aesthetic objects (Alexander 2008), a dual process of subjectification and objectification. Through reading and collecting and the voluntary submission to books' physical and formal properties (Gomart and Hennion 1999), readers draw books into the self and mould them as they themselves are changed through aesthetic immersion (Thumala Olave 2020).

What is most important to emphasise vis-a-vis the sociologies of reading that tie the social valuation of books and reading to their prestige and the social status that association with them can signal is that books do not only represent or stand in for these goods. They do not simply communicate social values. Books make these goods possible as they emerge in the very interaction between reader and object (the book is both a textual and a material object). I have found that book lovers obtain great pleasure from being surrounded by print copies of books; they value highly the material properties of the codex, while also reading digital books for their convenience; they invest time and money in acquiring, borrowing and organising books; they experience anxiety and pain when having to discard them; they enjoy gifting and recommending books but dislike lending their own copies for fear they might not return; they treasure books received as prizes and presents from loved ones; and they enjoy deeply the active role and stimulation which reading affords. In response to the assumption that such expressions of esteem for books are readily offered because reading is socially valued, a cultural sociology of reading can show that, indeed, reading is (now) associated with a range of highly valued goods, deemed worthy of collective protection across the world. Books can serve, in many milieus, to enhance their owners' social status. At the same time, books' allure and prestige would vanish if the interaction with them did not generate what people say it generates: the subjective experience and the realisation of sacred goods. The emergence of these goods, which are socially shaped, subjectively apprehended and valued in themselves, is what makes reading worthwhile and books the objects of affection (Thumala Olave 2020).

Here I want to suggest, as a hypothesis for further research, that the iconic power of books permeates textual objects more generally. Of course, not every text radiates the aura of authority or produces the pleasure or reverence that some artistic, sacred or scientific texts can elicit, and neither are these experiences shared by every person who has the ability to read. The degrees of influence (Solaroli 2015) and the scope and depth of texts' and books' iconic power requires empirical investigation. How 
far does the value and impact of books extend beyond the "reading class"? Are other texts also iconic? And if so, how? Two of the articles in this issue examine the iconicity of texts and reading.

In "The Felt Value of Reading Zines" Ash Watson and Andy Bennett advance one of the central concerns of the cultural sociology of reading, the study of how materiality matters in the relationship between readers and textual objects. Watson and Bennett study the practice of reading zines in Australia as a material/discursive, affective experience that is shaped by the iconic properties of these DIY objects. Reverberating through zines' content (mundane observations about plants, fruits or soda cans, the everyday experience of cancer) and surface form (zines are simple objects that require low levels of skill or material resources) are the deep meanings of the punk and feminist history of zines, the value of participatory politics and the counter-cultural resignification of production and consumption as active, intimate and intense. As material objects, zines represent a DIY ethos and aesthetic, and an anti-mainstream positioning, the commitment to these values among makers, readers and collectors. But as I have argued for books, zines do not simply signify these commitments. The pleasures brought about by zines' analogue, idiosyncratic, and fragile surfaces bring these commitments to life in the reading experience and generate care and love for the zines themselves and for each other among the members of zine communities. Readers of this issue will be able to glimpse at the zines carefully collected and analysed by Watson and Bennett thanks to the beautiful photographs that accompany their article.

The conceptualisation of the textual object as iconic is also central to Jan Váňa's project of a strong programme sociology of literature. In "Knowing through Feeling: The Aesthetic Structure of a Novel and the Iconic Experience of Reading", Váňa argues that bringing literature and sociology, the fictional and the non-fictional, into a symmetrical relationship can help sociologists produce a new kind of knowledge, one that captures and makes explicit the surplus of social meaning in works of literature. Váňa aims to achieve this by bringing together the aesthetic structure of the work itself, the novel Bliss was it in Bohemia by Czech author Michal Viewegh (1992), and the socio-historical background of its production and consumption. The empirical analysis in his article focuses on one side of the relationship: Váňa's reading of this novel, which he argues is iconic of the ambivalence and ethical ambiguity characterising ordinary life in Czechoslovakia, including the mundane negotiations with the communist regime.

In his contribution, Váňa writes that, by emphasising the reader's agency in my work (Thumala Olave 2018), I neglect the importance of the text itself, its aesthetic affordances, "as if the novels themselves were meaningless". In a related article (2020), I argue, like he does, that we should do away with the binary between communication and sensorial experience precisely because the effects of the reading experience, the coming to life of sacred goods, involve the practical fusion of these elements. Be that as it may, I stand by the idea that the agency of the reader should be at the centre. Attempting to capture the complexity of the interaction between reader, book and context while moving beyond reductive binaries does not, in my view, require the adoption of the principle of symmetry. Neither literature nor any text is able "to speak for itself", as Váňa writes. Unless it is read, a text is indeed 
meaningless. A print book can and does, however, have symbolic and iconic power when unread, when it is sitting on a bookshelf or lying about in a room. When unread the book's power does not come directly from the text (as a set of signs) but from the surfaces of the bound print copy and the social standing of the book as a type. The latter has meaning (is cherished or burned) on account of what happens when we read and because we remember that experience and what it produces, individually and collectively. In other words, materiality plays a crucial role (the print book and the literary object within it constrain the reader through their formal and surface features) but agency is not equally distributed, as Latour or Hennion might say. As Childress has shown, readers are guided by the text's "general interpretive directions" as they are "free to make their own meanings" (Childress 2017, p. 191) within those constrains.

The hypothesis that the iconic power of books extends beyond them is premised on the circulation and valuation of books in reading cultures. In a reading culture many of the goods that books make possible are ranked at the highest levels. This brings us to the question of literary value.

In "Spatial reading: evaluative frameworks and the making of literary authority", Günter Leypoldt is concerned with the basis on which lay and professional readers in the Anglophone literary system evaluate texts. He traces the historical transformation in the authority of a kind of reading he calls "spatial reading" and links this to Charles Taylor's modes of evaluation. One of Leypoldt's arguments is that the emergence of commercial markets for reading did not involve the replacement of weak for strong modes of evaluation, flat for spatial modes of reading. Instead, readers and authors shift between modes and weak-valued leisure reading coexists with a peer-oriented consecration space that he calls the laureate position in the artistic institutional system. This position, defined by a high-professional ethos, is occupied by consecrated authors (today's prize winners). Using the case of the controversy around the 2019 Nobel Prize of Literature awarded to Austrian author Peter Handke, who infamously attended the funeral of the Serbian politician Slobodan Milošević tried for war crimes in 2002, Leypoldt discusses the tension between the civil sphere and the literary artistic field. The former's principles of decency, freedom, and emancipation clash, he argues, with both the weak-valued readerly experience (some readers find Handke "difficult") and the amoral, formal criteria of the "state of the art" which justify the prize.

The tensions between strong and weak evaluations of literary objects emerge also in Anna Michelson's article, "The Politics of Happily-Ever-After: Romance Genre Fiction as Aesthetic Public Sphere". Michelson explores the meanings of romance novels for readers in the USA. These readers are drawn to the genre for similar reasons to those documented in previous research on romance reading - the desire to explore and learn about relationships and sex, the allure of getting lost in a gripping story as a way to escape the grudge of domestic or work life, the reassurance and hope contained in the happy ending that is the defining feature of the genre. Michelson's analysis, however, goes beyond confirming the prevalence of these motives among her readers. She examines how readers understand the genre in relation to socio-political issues and the normative debates about whether romance should incorporate political and social themes or be about entertainment alone. 
Michelson extends the concept of the aesthetic public sphere (Jacbos 2012) to the case of romance readers and writers. She argues that the experience of reading popular romance fiction creates a space for political discourse both within the pages of the novels and in the community of romance readers and writers, even when the expectations set by the formal features of the genre require a central love story and a happy ending. In line with the cultural sociology of reading, the article shirks the opposition between domination and resistance and posits that "entertainment, as a temporary retreat, can complement engagement" (p. 30) with socio-political issues.

Michelson's piece speaks to another central concern of the cultural sociology of reading. The role of pleasure as a key feature of and justification for reading. I have argued that the overall positive affective states that reading affords together with books' content equip readers with devices to fashion and refigure their subjectivity while caring for themselves and relating to others (Thumala Olave 2018). In Michelson's study, reading romance is explicitly valued as a way to "escape" to alternative, fictional scenarios. What is notable is that the reasons why these readers want to go into the imaginary worlds in the novels that they most appreciate are anything but mindless or banal. As Leypoldt shows in his article, readers' stances shift between modes of strong and weak evaluation. Here, one of the most devalued genres (which from the perspective of literary institutions would be apt for a regime of weak evaluation akin to the unjustifiable preference for one flavour of ice cream over another) is, in fact, the object of strong evaluation. The content of these readers' aspirations, the things they most care about and about which (or with which) they are passionate (Gomart and Hennion 1999) include the establishment of a meaningful romantic relationship, personal development, and the continuance of hope. Michelson's article demonstrates that the quintessentially escapist and regressive genre of romance fiction can generate a space, both personal and institutional, for the examination and debate of serious political and social issues: the threats to democracy, racism, gender norms. As a literary form (no matter how stigmatised on account of its mostly female membership and low quality), romance appears to be as iconic of the zeitgeist in the contemporary United States as Váňa's chosen novel is of the 1970s and 1980s in Czechoslovakia.

Álvaro Santana Acuña's article contributes to the research on valuation and to answering the question about how those who are tasked with the role of evaluating the worth of a cultural object, cultural intermediaries, reduce complexity in the face of uncertainty. In particular, how the process of reconciling heterogenous interpretations of cultural objects occurs transnationally. Santana Acuña uses the case of Gabriel Garcia Marquez's 1967 novel One Hundred Years of Solitude (Cien Años de Soledad) to analyse how the first professional reviewers in various countries handled the uncertainty posed by the novel, which was written by a little-known author, challenged existing aesthetic categories and was commercially successful. Moving a step further from his previously published work on the topic, Santana Acuña's argument is that among the reviewers' individual strategies for sense-making, the most effective one was that of resignifying the relatively unknown label of magical realism. Reappropriating, or recycling as Santana Acuña calls it, an aesthetic category used only by regional critics and making it circulate globally, reviewers had by the end of the 1960 s both altered the meaning of the label and set the basis for 
the normalisation and stabilisation of the meaning and worth of the novel as innovative. The article offers details of the different strategies deployed by reviewers to make sense of the novel and in the process consolidate the label that would become synonymous with Latin American literature and culture more generally for many years to come. Natalie Heinich writes that "the actor, far from passively evaluating a given object, actively participates in its very definition" (Heinich 2020, p. 3). Santana Acuña shows how the initial reviewers of One Hundred Years of Solitude did just that.

Daniel Allington's article entitled "Customer reviews of 'highbrow' literature: a comparative reception study of The Inheritance of Loss and The White Tiger" focuses on styles of evaluation among lay readers. Based on the exploratory quantitative analysis of amazon customer reviews of two novels, he finds that the evaluative language of these reviews matches that of professional critics. The convergence could be seen as the success of cultural brokers and intermediaries in shaping the cognitive schemas with which non-professional readers evaluate books: the force of the 'peer-oriented taste' of a minority group with disproportionate influence discussed in Leypoldt's piece, or the resignification traced by Santana Acuña, which paves the way for later orchestration (the agreement between reviewers). Yet, the enjoyment of the novels among readers in Allington's piece appears identical to the enjoyment of the activity of interpreting their formal qualities. The implications of this are significant for a cultural sociology of reading that proposes we explore the imbrications of pleasure and understanding (Thumala Olave 2018). Allington's findings point to the presence among non-professional readers of the critical style that prevails among professional critics, one characterised by detachment and the suspicion of pleasure. Yet, the fact that the language of critical distance is bound to notions of care highlights the importance of attachment in reading. It brings home the point that our understanding of books' allure remains partial, at best, if we assume a clash between analysis and enjoyment.

\section{Final thoughts: styles of reading and styles of theorising}

In the background of most of the articles in this issue, and the foreground of Jan Váňa's piece, is the question about the relationship between reading and social theory. Texts are the medium in which scholarship is produced and circulated, the metaphor upon which a part of social theory is built, and both the method for and object of analysis of much sociological work. There is an important tradition of social thought about literature that explores what sociology can learn from poetic forms of expression (Abbott 2007; Brown 1977), the enduring use of metaphors in social theorising (Turner 2010), or the idea that literature offers intimations about social reality that cannot be accessed as easily in the language of the social sciences (Lepenies 1988; Becker 2007). One important question raised by these discussions is that about the kind of knowledge that is literature and how to translate it into sociology. If literature is more truthful (Williams 2002) than social scientific accounts, if it offers a unique depth of insight because it adumbrates at the meanings of the whole or the totality of our everyday experience of the social, can this knowledge be 
systematised? Abbott has critiqued narrative forms of sociology (both quantitative and qualitative efforts at explanation) and called for a lyrical sociology, an engaged and non-ironic stance towards both the object and the subject of the enquiry. Emotional engagement, ethical commitment and the use of imagery and personification are seen as compatible with rigour, discipline and a scientific framework. Similar issues were raised in this journal around Biernacki's (2012) critique of coding as cutting-up social experience into discrete, artificial pieces in order to then reassemble the whole again and his defence of the rigour of humanistic techniques (Biernacki 2015; Lee and Levi Martin 2015; Reed 2015; Spillman 2015). Váňa’s project seems consistent with the goal of approaching social life as a meaningful whole and using literature as a fitting way to do that.

Beyond this journal and this special issue, the interest in conceptualising and extending the connections between social theory and literature is ongoing and productive. Just a few recent examples: The articles in Theory, Culture and Society's e-special collection on fiction and social theory are organised by Beer (2016) in his editorial introduction as conceptualising fiction as (a) inspiration for theoretical development, (b) a documentary resource and (c) an object of theoretical analysis (Beer 2016). Frisby's (1992) article in the collection about Krakauer's work on the detective novel conceives of it as both allegorical of modernity and as itself a social analysis of modern life (a theme recently revisited by Luc Boltanski's study of the detective novel as epitomising a modern mode of sometimes 'paranoid' inquiry and critique (Boltanski 2014; see also Ossandón 2020; De Cock et al. 2020). Since 2019, The Sociological Review publishes a special section on Sociological Fiction edited by Ash Watson (a contributor to this issue). Watson recently joined the group of sociologists who, like Richard Sennett (1987, 1984, 1982), have explored social themes through fiction, with the publication of her sociological novel Into the Sea (2020). Watson's novel seeks to simultaneously "do public sociology", "illustrate sociological concepts", and analyse "how narratives work in the social world" (Watson 2019). This and other sociological fictional works can be seen as attempts to reunite literature and social science, which as Richard Swedberg writes, citing Lepenies (1988), overlapped much more often in the beginnings of the discipline of sociology (Swedberg 2016, p. 124), before strict disciplinary boundaries developed. In 2020, the editors of the journal Valuation Studies issued a call for papers on the theme of "Valuation as a semiotic, narrative, and dramaturgical problem" based on the premise that "valuation is at least in part about signs" and seeking to explore the use of semiotics, discourse, narrative and performance in studies of valuation (Muniesa and Ossandón 2020). The first issue of 2021 of Sociological Forum features a discussion of the connections between sociology and literature sparked by Peter J. Stein's 2019 memoir, A Boy's Journey: From Nazi-Occupied Prague to Freedom in America. In her commentary of the book, Simko (2021) refers to the parallels between the memoir and John Stuart Mill's sociological imagination including the capacity to capture the contingency of life (a theme which is also central to Váňa's analysis in this issue).

One aspect that appears to have received comparably less attention is that about the possible connections between styles of reading and styles of theorising. Are there identifiable properties in the act of reading that are conducive to certain kinds 
of thought? Is the training in a form of reading the result of the attachment to a form of theory or the other way around?

Given the centrality of the encounter between text and reader in its approach, a cultural sociology of reading could turn its gaze towards the practice of academic reading. This is something that literary scholars do much more frequently, given the inextricable link between the craft of literary criticism and reading. Sociologists, used to running regressions, coding visual images or "going to the field", arguably have a wider variety of tools at their disposal, not all of them textual. It seems uncontroversial to say that styles of reading accompany styles of theorising, in the sense that the conceptual apparatus of, for example, critical theory tends to be paired with "reading against the grain", "unveiling" and "disclosing", or that theories of deconstruction are executed via "undoing" and the opening of texts to the "conditions of their production", or that a postmodernist position involves "ironic" or "paradoxical" forms of reading and so on. Insofar as certain reading styles and theories are frequently paired, a cultural sociology of reading can fruitfully examine what makes them come together. Given that it draws on theories of reception, materiality and social practice and that it is attentive to the aesthetic, a cultural sociology of reading is very well placed to examine how we read when doing social theory and to what effects.

As I prepared to write this introduction, I asked a few fellow sociologists to tell me if they think of what they do as "reading the social" and what their position is regarding the metaphor of "society as text" famously articulated by Ricoeur (1973). The result of my tiny and informal survey was that few see their endeavours as within "the model of the text". Not because they have strong programmatic objections to the metaphor or to interpretive sociology broadly understood but because their research practice tends to be led by the object of their concern rather than a prior commitment to ontological or epistemological positions. I suspect that this is a general approach. If what sociologists are trying to understand or explain can be fruitfully examined in terms of meaning, textual or discourse analysis, for example come in handy. But this is not always or often the case and the pragmatic approach makes sense. At the same time, this suggests that a cultural sociology of reading may be a good site to explore how essential the textual form is for every kind of sociological research and theorising, regardless of which theoretical "church" or sensibility the researcher ascribes to or which set of tools are deployed in each project. The central role of texts I am referring to is not only that, even in the age of algorithms, computer programming or light-speed financial trading, texts remain key for social interaction, or that social theory itself is unthinkable without texts. Rather, the question is what are the features of the encounter between reader and text, of the act of reading for specific theoretical traditions or schools of thought? If there are interdependencies between style and content, what might be driving these? How much does reading in a particular style shape the ideas generated?

One outcome of an enquiry into sociologists' styles of reading and their theoretical results might be the need to contend with the fact that there are limits to what can be done and understood sociologically and that those limits are posed by the form and medium of the text. If we consider, for example, the material turn in sociology, the sociology of the body and emotions, the aesthetic projects of scholars 
such as Andrew Abbott, Georgina Born, Jeffrey Alexander or Dominik Bartmanski, developments that in very different ways can be said to share an effort to bring the aesthetic, sensorial or material to the fore, we can see that although significant work has been done to capture some of the aesthetic or affective dimensions of social life, there is an arguably irresolvable tension between pre-linguistic "lived experience" (or what phenomenologists call the duree Schutz 1967) and the way in which we make sense of these experiences. Theorising these experiences requires the conversion of them into text by either the subjects of the study, in their first order interpretations, or their interpreters' second order accounts (Bruner 1991). Such a translation is limited not because it may involve reductive methods (Biernacki 2012; Douglas and Ney 1998) but because the very form of the textual medium excludes parts of the lived experience which are meaningful in non-textual ways. A cultural sociology of reading can contribute to the understanding of reading, both lay and academic, in ways that are open to what cannot be verbalised while acknowledging the firm grip of the hermeneutic circle, the constraints and creative possibilities of thinking about and with texts.

Acknowledgements I am grateful to Jeffrey Alexander for the invitation to guest edit this special issue and to Steve Kemp for our conversations about reading and social theory. Special thanks to Anne Marie Champagne for her outstanding work as managing editor.

\section{References}

Abbott, Andrew. 2007. Against Narrative: A Preface to Lyrical Sociology. Sociological Theory 5: 67-99. Alexander, Jeffrey. 2006. The Civil Sphere. Oxford: Oxford University Press.

Alexander, Jeffrey. 2003. The Meanings of Social Life: A Cultural Sociology. Oxford: Oxford University Press.

Alexander, Jeffrey. 2008. Iconic Experience in Art and Life-Surface/Depth Beginning with Giacometti's Standing Woman. Theory, Culture and Society 25 (5): 1-19.

Alexander, Jeffrey. 2010. The Celebrity-Icon. Cultural Sociology 4: 323-336.

Alexander, Jeffrey. 2020. The Performativity of Objects. Sociologisk Forskning 57: 381-409.

Alexander, J., D. Bartmański, and B. Giesen. 2012. Iconic Power: Materiality and Meaning in Social Life. New York: Palgrave Macmillan.

Altieri, Charles. 2003. The Particulars of Rapture: An Aesthetics of the Affects. Ithaca: Cornell University Press.

Anderson, Benedict. [1983] (2006). Imagined Communities: Reflections on the Origin and Spread of Nationalism. Revised Edition. London: Verso.

Aubry, Timothy. 2011. Reading as Therapy. What Contemporary Fiction Does for Middle-Class Americans. Iowa City: University of Iowa Press.

Aubry, Timothy. 2018. Guilty Aesthetic Pleasures. Cambridge: Harvard University Press.

Baldwin, James, and Margaret Mead. 1971. A Rap on Race. Philadelphia: Lippincott, J. B.

Barton, David, and Mary Hamilton. 1998. Local Literacies. Reading and Writing in One Community. London: Routledge.

Becker, Howard S. 2007. Telling About Society. Chicago: University of Chicago Press.

Beer, David. 2016. Fiction and Social Theory: E-Special Introduction. Theory, Culture and Society 33: 409-419.

Benjamin, Walter. [1955] 2015. Unpacking My Library. In Illuminations, ed. Hannah Arendt. London: Penguin Random House.

Bennett, Tony, Mike Savage, Elizabeth Silva, Alan Warde, Modesto Gayo-cal, and David Wright. 2009. Culture, class, distinction. Routledge: Oxon. 
Biernacki, Richard. 2012. Reinventing Evidence in Social Inquiry: Decoding Facts and Variables. New York: Palgrave Macmillan.

Biernacki, Richard. 2015. Erratum: How to Do Things with Historical Texts. American Journal of Cultural Sociology 3: 311-352.

Billington, Josie. 2011. 'Reading for Life': Prison Reading Groups in Practice and Theory. Critical Survey 23: $67-85$.

Blumenberg, Hans. [1981] 2000. La Legibilidad del Mundo. Barcelona: Paidos.

Boltanski, Luc. 2014. Mysteries and Conspiracies: Detective Stories, Spy Novels and the Making of Modern Societies. Cambridge: Polity Press.

Bolter, Jay David, and Richard Grusin. 2000. Remediation. Understanding New Media. Cambridge: The MIT Press.

Borsuk, Amaranth. 2018. The Book. Cambridge: The MIT Press.

Brown, Richard H. 1977. A Poetic for Sociology. Toward a Logic of Discovery for the Human Sciences. Cambridge: Cambridge University Press.

Bruner, Jerome Seymour. 1991. The Narrative Construction of Reality. Critical Inquiry 18: 1-21.

Chartier, Roger. 2018. Introduction: Reading Practices and the Materiality of Texts. French Historical Studies 41: 397-401.

Childress, C. Clayton., and Noah E. Friedkin. 2012. Cultural Reception and Production: The Social Construction of Meaning in Book Clubs. American Sociological Review 77: 45-68.

Childress, Clayton. 2017. Under the Cover: The Creation, Production, and Reception of a Novel. Princeton: Princeton University Press.

Cock, De., Damian O’Doherty. Christian, Christian Huber, and Sine N. Just, eds. 2020. Organization 2666. Literary Troubling, Undoing and Refusal. Wiesbaden: Springer.

Douglas, Mary, and Steven Ney. 1998. Missing Persons. A Critique of the Social Sciences. Berkeley: University of California Press.

Driscoll, Beth. 2014. The New Literary Middlebrow. Tastemakers and Reading in the Twenty-First Century. Basingstoke, New York: Palgrave Macmillan.

Dunch, R. 2002. Beyond Cultural Imperialism: Cultural Theory, Christian Missions, and Global Modernity. History and Theory 41: 301-325.

Felski, Rita. 2008. Uses of Literature. Malden: Wiley-Blackwell.

Felski, Rita. 2020. Hooked. Art and Attachment. Chicago: The University of Chicago Press.

Frisby, David. 1992. Between the Spheres: Siegfried Kracauer and the Detective Novel. Theory, Culture and Society 9: 1-22.

Gomart, Emile, and Antoine Hennion. 1999. A Sociology of Attachment: Music Amateurs, Drug Users. The Sociological Review 47: 220-247.

Griswold, Wendy, Elizabeth Lenaghan, and Michelle Naffziger. 2011. Readers as Audiences. In The Handbook of Media Audiences, ed. Virginia Nightingale. Hoboken: Blackwell Publishing.

Griswold, Wendy, Terry McDonnell, and Nathan Wright. 2005. Reading and the Reading Class in the Twenty-First Century. Annual Review of Sociology 31: 127-141.

Griswold, Wendy. 1981. American Character and the American Novel: An Expansion of Reflection Theory in the Sociology of Literature. American Journal of Sociology 86: 740-765.

Griswold, Wendy. 2000. Bearing Witness: Readers, Writers, and the Novel in Nigeria. Princeton: Princeton University Press.

Habermas, Jurgen. 1989. The Structural Transformation of the Public Sphere. Cambridge: The MIT Press.

Hartley, Jenny. 2001. Reading Groups. Oxford: Oxford University Press.

Heinich, Natalie. 2020. A Pragmatic Redefinition of Value(s): Toward a General Model of Valuation. Theory, Culture and Society. https://doi.org/10.1177/0263276420915993.

Hennion, Antoine. 2007. Those Things That Hold Us Together: Taste and Sociology. Cultural Sociology 1: $97-114$.

Hennion, Antoine. 2004. Pragmatics of Taste. In The Blackwell Companion to the Sociology of Culture, ed. Mark Jacobs and Nancy Hanranhan. Oxford: Blackwell.

Hennion, Antoine, and Stephen Muecke. 2016. From ANT to Pragmatism: A Journey with Bruno Latour at the CSI. New Literary History 47: 289-308.

Iser, Wolfgang. 1980. Interaction between Text and Reader. In The Reader in the Text: Essays on Audience and Interpretation, ed. Susan Suleiman and Inge Crosman, 106-119. Princeton: Princeton University Press. 
Jacbos, Ron. 2012. Entertainment media and the aesthetic public sphere. In Oxford Handbook of Cultural Sociology, ed. Jeffrey C. Alexander, Ronald N. Jacobs and Philipp Smith, 318-342. Oxford and New York: Oxford University Press.

Jauss, Hans Robert. 1982. Aesthetic Experience and Literary Hermeneutics. Minneapolis: University of Minnesota Press.

Kirsch, T.G. 2007. Ways of Reading as Religious Power in Print Globalization. American Ethnologist 34: 509-520.

Lee, Monica, and John Levi Martin. 2015. Coding, Counting and Cultural Cartography. American Journal of Cultural Sociology 3: 1-33.

Lepenies, Wolf. 1988. Between Literature and Science: The Rise of Sociology. Cambridge: Cambridge University Press.

Long, Elizabeth. 2003. Book Clubs. Women and the Uses of Reading in Everyday Life. Chicago: University of Chicago Press.

Manguel, Alberto. 1997. A History of Reading. London: Harper Collins.

Manguel, Alberto. 2010. A reader on Reading. New Haven: Yale University Press.

Meyer, J.W., F.O. Ramirez, and Y.N. Soysal. 1992. World Expansion of Mass Education, 1870-1970. Sociology of Education 65: 128-149.

Muniesa, Fabian and José Ossandón. 2020. Valuation Studies Thematic Call. https://valuationstudies.liu. se/valuation_as_a_semiotic_problem.

Nagel, Ineke, and Marc Verboord. 2012. Cultural capital formation from adolescence to early adulthood. The impact of family and education on book reading. Acta Sociologica 55: 243-59.

Ossandón, José. 2020. Reading as Theorizing. A Conjecture Based on the Savage Detectives' Mode of Inquiry. In Organization 2666: Literary Troubling, Undoing and Refusal, ed. C. De Cock, D. O'Doherty, C. Huber, and S. Just. Wiesbaden: Springer.

Phelan, James. 2007. Experiencing Fiction: Judgments, Progressions, and the Rhetorical Theory of Narrative. Columbus: Ohio State University Press.

Price, Leah. 2019. What We Talk About When We Talk About Books. The History and Future of Reading. New York: Basic Books.

Reed, Adam. 2002. Henry and I: An Ethnographic Account of Men's Fiction Reading. Ethnos 67: $181-200$.

Reed, Isaac. 2015. Counting, Interpreting and Their Potential Interrelation in the Human Sciences, American Journal of. Cultural Sociology 3: 353-364.

Ricoeur, Paul. 1973. The Model of the Text: Meaningful Action Considered as a Text. New Literary History 5: 91-117.

Rose, Jonathan. 2001. The Intellectual Life of the British Working Classes. New Haven: Yale University Press.

Schutz, Alfred. 1967. The Phenomenology of the Social World. Evanston: Northwestern University Press.

Scotland National Museums. 2019. Robots Exhibition, 18 Jan-5 May. https://www.nms.ac.uk/nationalmuseum-of-scotland/things-to-see-and-do/past-exhibitions/robots/. Accessed 17 Feb 2021.

Sennett, Richard. 1982. The Frog Who Dared to Croak. New York: Farrar, Strauss and Giroux.

Sennett, Richard. 1984. An Evening of Brahms. New York: Knopf.

Sennett, Richard. 1987. Palais-Royal. New York: Knopf.

Simko, Cristina. 2021. Memoir and the Sociological Imagination. Sociological Forum 36: 272-276.

Solaroli, Marco. 2015. Iconicity. A Category for Social and Cultural Theory. Sociologica 1: 1-52.

Sontag, Susan. 1967. Against Interpretation: and other essays. London: Eyre and Spottiswoode.

Spillman, Lynette. 2015. Ghosts of Straw Men: A Reply to Lee and Martin. American Journal of Cultural Sociology 3: 365-379.

Steiner, George. 1978. On Difficulty and Other Essays. Oxford: Oxford University Press.

Striphas, Theodore G. 2009. The Late Age of Print. Everyday Book Culture from Consumerism to Control. New York: Columbia University Press.

Swedberg, Richard. 2016. The Literary Author as a Sociologist? Among French Peasants by August Strindberg. Journal of Classical Sociology 16: 124-130.

Sweeny, Megan. 2010. Reading is My Window: Books and the Art of Reading in Women's Prisons. Chapel Hill: University of North Carolina Press.

Sweeny, Megan. 2012. "Keeping it real" Incarcerated Women's Readings of African American Urban Fiction. In From Codex to Hypertext. Reading at the Turn of the Twenty-First Century, ed. Anouk Lang. Amherst: University of Massachusetts Press. 
Taylor, Charles. 1989. Sources of the Self: The Making of the Modern Identity. Cambridge: Harvard University Press.

Taylor, Helen. 2019. Why Women Read Fiction. The Stories of Our Lives. Oxford: Oxford University Press.

Thumala Olave, María Angélica. 2018. Reading Matters. Towards a Cultural Sociology of Reading. American Journal of Cultural Sociology 63: 417-454.

Thumala Olave, María Angélica. 2020. Book Love. A Cultural Sociological Interpretation of the Attachments to Books. Poetics 81: 1-11.

Turner, Charles. 2010. Investigating Sociological Theory. London: Sage.

Watson, Ashleigh. 2019. Some Thoughts on 'Sociological Fiction'. In The Sociological Review. Sociology \& Literature. https://www.thesociologicalreview.com/some-thoughts-on-sociological-fiction/. Accessed 22 Jan.

Watson, Ashleigh. 2020. Into the Sea. Leiden: Brill.

Williams, Bernard. 2002. Truth and Truthfulness: An Essay in Genealogy . Princeton: Princeton University Press.

Winterson, Jeanette. 2012. Why Be Happy When You Could be Normal? London: Vintage.

Wolf, Maryanne. 2018. Reader Come Home: The Reading Brain in a Digital World. Woodstock: Harper.

Wu, Angela Xiao. 2014. The Shared Pasts of Solitary Readers in China: Connecting Web Use and Changing Political Understanding Through Reading Histories. Media, Culture and Society 36: 1168-1185.

Publisher's Note Springer Nature remains neutral with regard to jurisdictional claims in published maps and institutional affiliations.

María Angélica Thumala Olave is Lecturer in Global Sociology at the School of Social and Political Science, University of Edinburgh. Her work in cultural sociology examines practices of self-understanding and justification in secular and religious contexts. Her research has appeared in the American Journal of Cultural Sociology, Religion, Social Compass, British Journal of Sociology and Sociological Review. She is writing a monograph entitled The Love of Books. Attachment to a Changing Cultural Object. 